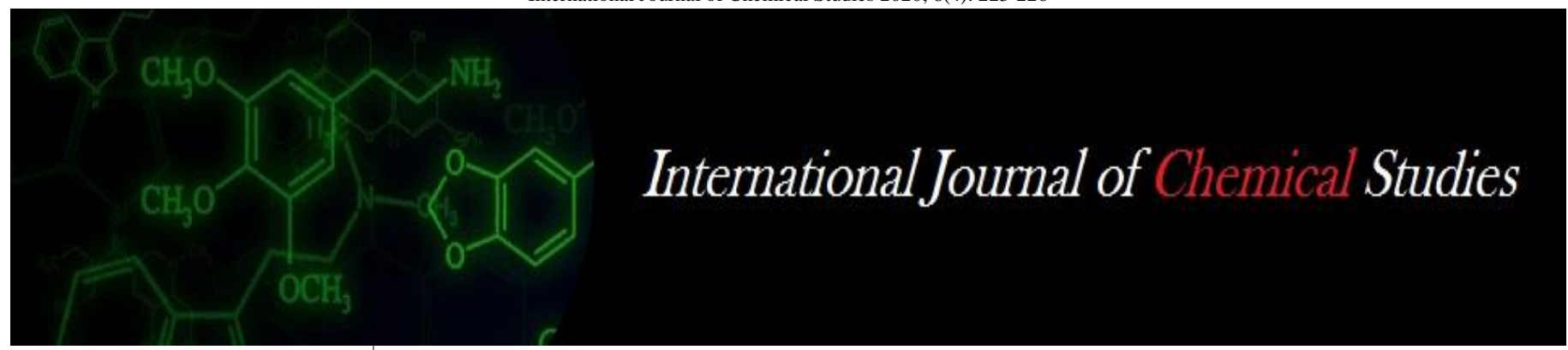

P-ISSN: 2349-8528

E-ISSN: 2321-4902

www.chemijournal.com

IJCS 2020; 8(4): 223-226

(C) 2020 IJCS

Received: 20-05-2020

Accepted: 24-06-2020

Kishore Varma $P$

Regional Agricultural Research

Station, Anakapalle,

Visakhapatnam, Andhra

Pradesh, India

Chandrasekhar V

Regional Agricultural Research

Station, Anakapalle,

Visakhapatnam, Andhra

Pradesh, India

Bharathalakshmi M

Regional Agricultural Research

Station, Anakapalle,

Visakhapatnam, Andhra

Pradesh, India

Srilatha Vani Ch

Regional Agricultural Research

Station, Anakapalle,

Visakhapatnam, Andhra

Pradesh, India

Jamuna $P$

Regional Agricultural Research

Station, Anakapalle,

Visakhapatnam, Andhra

Pradesh, India

Corresponding Author:

Kishore Varma P

Regional Agricultural Research

Station, Anakapalle,

Visakhapatnam, Andhra

Pradesh, India

\section{Field evaluation of fungicides for the management of whip smut in sugarcane caused by Sporisorium scitamineum}

\author{
Kishore Varma P, Chandrasekhar V, Bharathalakshmi M, Srilatha Vani \\ Ch and Jamuna $P$
}

DOI: https://doi.org/10.22271/chemi.2020.v8.i4c.9693

\begin{abstract}
Smut, incited by Sporisorium scitamineum, is one of the major diseases of sugarcane causing economic yield losses to sugarcane growers as well as sugar industry. A field trial was conducted for three consecutive seasons from 2017-18 to 2019-20 at RARS, Anakapalli to test the efficacy of seven fungicides against whip smut of sugarcane. In plant crop, three budded setts of the smut susceptible cultivar, CoA 92081, were artificially inoculated with smut spore suspension for 30 minutes followed by dipping in fungicidal solution for 15 minutes prior to planting. In ratoon crop, the fungicidal treatments were imposed by spraying of fungicides immediately after ratooning followed by second spray at 30 days after ratooning. Smut incidence was recorded at fortnightly interval from first smut whip emergence till harvest. The experimental results revealed that sett treatment with azoxystrobin + tebuconazole @0.1\% has recorded significantly lower incidence of smut in plant crop compared to other treatments but was on par with trifloxystrobin+tebuconazole@0.1\% and propiconazole@0.1\% treatments. In ratoon crop, spraying with tebuconazole @ $0.1 \%$ or trifloxystrobin+tebuconaole @ $0.1 \%$ was found effective against whip smut disease with less disease incidence and higher cane yield compared to other treatments. Overall results of plant and ratoon crop indicated that sett treatment with azoxystrobin+tebuconazole at the time of planting and spraying of tebuconazole twice, i.e., first spray at ratoon initiation and second spray at 30 days after ratooning was proved effective in the management of whip smut in sugarcane.
\end{abstract}

Keywords: Sugarcane, whip smut, fungicides, Sporisorium, sett treatment, ratoon

\section{Introduction}

Sugarcane is an important commercial crop of India grown in an area of 47.3 lakh ha with a production of 376.9 million tonnes and average yield of $79.68 \mathrm{t} /$ ha (FAOSTAT, 2018) ${ }^{[7]}$. The productivity of sugarcane is low in most parts of the country due to several biotic and abiotic stresses. Among biotic stresses, smut disease of sugarcane, caused by a basidiomycete fungus, Sporisorium scitaminae (Syn: Ustilago scitaminae Syd.) is a serious disease of sugarcane worldwide causing economic yield loss and reduction in cane quality, especially in susceptible varieties (Viswanathan and Rao., 2011; Wada et al., 2016) ${ }^{[20,21,22]}$. Incidence of smut reduces the height and girth of the cane, tillering ability of the plant, cane tonnage, total solids and sucrose content in juice and ratio of sugars to fibre making sugar extraction difficult (James, 1973; Ramesh Sundar et al., 2012; Sandhu et al., 1969; Xiupeng et al., 2019) ${ }^{[9,14,16,23]}$. Smut severity depends on the type of infection (primary or secondary), type of crop (plant or ratoon) and time of infection (early or late). Severity of smut increases with primary infection and planting of naturally infected canes reduce sett germination and enhance smut incidence and cane yield losses in susceptible varieties.

Losses in ratoon are more severe than in plant crop. For instance, seventy per cent reduction in yield due to smut was recorded in India in ratoon as compared to $29 \%$ in plant crops (Chona, 1943) ${ }^{[6]}$. Further, infection in early stage of crop growth leads to death of smutted stools and late infections may escape economic losses (Mohan Rao and Prakasam, 1956) ${ }^{[11]}$.

Rouging of smutted whips, use of healthy planting material, use of resistant varieties, avoiding ratooning of badly infected fields, crop rotation with Lucerne or maize or green manure crop (Robinson, 1959) ${ }^{[15]}$, treatment of setts with hot water, fungicides and bioagents followed by spray with fungicides have been suggested by several authors for smut management 
(Abera et al., 2009; Bhuiyan et al., 2012; Ferriera and Comstock, 1989; Sundravadana et al., 2011) $\left[\begin{array}{llll}1,4, & 8,18] .\end{array}\right.$ Bhuiyan et al. (2015) ${ }^{[5]}$ obtained good control of smut disease with flutriafol when applied at rates of 100-400 $\mathrm{g}$ a.i/ha mixed with fertilizer and at rates of $12.5 \mathrm{~g}$ a.i/100 $\mathrm{L}$ and above when applied as a 10 minute dip of setts. Similarly, dipping of three budded setts in a solution of Trichoderma viride $\left(1 \times 10^{6}\right.$ spores $/ \mathrm{ml})$ or propiconazole $(0.2 \%)$ was found promising in reducing the smut disease (Paramdeep et al., 2014) [13]. Further, some of the bioagents, Pseudomonas guariconensis (strain ST4), isolated from sugarcane rhizosphere was reported to inhibit the mating of $S$. scitamineum bipolar sporidia and addition of $2 \%$ glucose to the bacterial inoculum enhanced the bacterial biocontrol efficiency (Liu et al., 2017) ${ }^{[10]}$. Likewise, neem leaf and neem fruit extracts at $60 \mathrm{~g} / \mathrm{L}$ were found to reduce smut incidence under field conditions (Wada and Dangana, 2016) ${ }^{[21,22]}$.

In Andhra Pradesh, the variety, CoA 92081 (87A 298) is very popular among the sugarcane growers since 2002 owing to its good agronomic traits and ratoonability. However, farmers couldn't reap the full potential of this variety due to its susceptibility to smut disease, especially under ratoons. Over a decade, limited fungicides are under use for smut management in Andhra Pradesh which may lead to resistance development in the pathogen. Hence, the present investigation was planned to study the efficacy of new fungicides as sett treatment and spray for effective management of smut disease of sugarcane in plant and ratoon crops.

\section{Materials and Methods}

A field experiment was conducted in research farm of Regional Agricultural Research Station, Anakapalli, Andhra Pradesh during the crop seasons of 2017-18, 208-19 and 2019-20. The trial was planted during February of 2017-18 and 2018-19 crop seasons and harvested during December of respective years. In plant crop, three budded setts were artificially inoculated with teliospores of smut pathogen prior to planting. Sporisorium scitamineum teliospores freshly collected from smut susceptible sugarcane varieties were used as a source of inoculum. Freshly collected whips were air dried under shade and teliospores were collected in butter paper bags and are stored in a desiccator under anhydrous calcium chloride for further use. The three budded setts of the sugarcane cultivar were steeped in a spore suspension of over 90 per cent viability and with a spore load of one million spores per milliliter. Later, the smut inoculated setts were treated with fungicidal solution for 15 minutes prior to planting. The experiment was laid out in a randomized block design with 9 treatments as detailed below and replicated thrice.

Table 1: Details of treatments of the experiment

\begin{tabular}{|c|c|c|}
\hline Treatment & Particulars & Dosage \\
\hline T1 & Azoxystrobin + Tebuconazole @ 0.1\% & $1 \mathrm{ml} / \mathrm{L}$ \\
\hline T2 & Trifloxystrobin + Tebuconazole @0.1\% & $1 \mathrm{ml} / \mathrm{L}$ \\
\hline T3 & Propiconazole @ 0.1\% & $1 \mathrm{ml} / \mathrm{L}$ \\
\hline T4 & Difenaconazole @ 0.1\% & $1 \mathrm{ml} / \mathrm{L}$ \\
\hline T5 & Tebuconazole @ 0.1\% & $1 \mathrm{ml} / \mathrm{L}$ \\
\hline T6 & Carbendazim @ $0.1 \%$ & $1 \mathrm{~g} / \mathrm{L}$ \\
\hline T7 & Hexaconazole @ 0.2\% & $2 \mathrm{ml} / \mathrm{L}$ \\
\hline T8 & Inoculated control & \\
\hline T9 & Healthy control & \\
\hline
\end{tabular}

All the cultural practices like weeding, fertilizer management earthing up, T.T.propping were done as per recommendations to the plant crop. After the harvest of plant crops of 2017-18 and 2018-19 crop seasons, the stubbles were sprayed with the fungicides on ratoon initiation as mentioned in the treatments $\mathrm{T} 1$ to $\mathrm{T} 7$ and the second spray was given 30 days after first spray. Data on smut incidence was recorded in plant and ratoon crops from first appearance of smutted whips till harvest at fortnightly intervals. Plot wise yield was recorded in ratoon crop as the yield loss is more pronounced only in ratoon crop. Based on gross returns and cost of cultivation in different treatments the benefit crop ratio was calculated. The data on percent disease incidence (PDI) and yield were analyzed statistically as suggested by Panse and Sukatma $(1985)^{[12]}$.

\section{Results and Discussion}

Among various fungicides tested as sett treatment (Table 2) for the management of sugarcane whip smut, least disease incidence was observed in sett treatment with azoxystrobin + tebuconazole $(3.53 \%)$ which was at par with propiconazole $(4.69 \%)$ and trifloxystrobin + tebuconazole $(4.93 \%)$. While highest smut incidence was recorded in untreated control (29.69\%) followed by carbendazim $(20.29 \%)$. Though, smut incidence was statistically at par in plots treated with azoxystrobin + tebuconazole or trifloxystrobin + tebuconazole, propiconazole and tebuconazole, no smut incidence was recorded in azoxystrobin + tebuconazole treated plots upto 3 months after planting. The results are in accordance with earlier reports, where sett treatment with fungicides like triademifon $(0.1 \%)$ or propiconazole $(0.1 \%)$ for 2 hours is effective for smut management (Bharathi, 2009) [3]. However, the reduced period of exposure of setts to the fungicides tested in the present study, i.e., for 15 minutes, was also found effective for smut management which may be attributed to the enhanced inhibitory effect of combination products (strobilurins and triazole) to the smut propagules. Azoxystrobin + tebuconazole applied to the seed cane provided good protection against smut in the plant crop where the setts were artificially inoculated with smut spore suspension. No incidence of smut was recorded in the Azoxystrobin + tebuconazole treated plots for initial 3 months which reflects the eradicative and protective nature of the fungicide. Overall, the treatment of seed cane with either triazoles alone or in combination with strobilurins was effective for smut management compared to treatment with benzimidazole fungicide, carbendazim. Moreover, use of healthy seed cane for planting has also reduced smut disease incidence compared to inoculated control.

In ratoon crop, least smut incidence (Table 3) was observed in plots sprayed with tebuconazole $(4.93 \%)$ which was at par with trifloxystrobin + tebuconazole $(6.48 \%)$ and azoxystrobin + tebuconazole $(9.38 \%)$. High smut incidence was recorded in inoculated control (31.11\%) followed by carbendazim $(23.93 \%)$ treated plots. Yield data presented in Table 4 revealed that highest yield was obtained in tebuconazole treated plots $(75.11 \mathrm{t} / \mathrm{ha})$ which was followed by spraying with trifloxystrobin + tebuconazole $(75.33$ t/ha and azoxystrobin + tebuconazole $(71.00 \mathrm{t} / \mathrm{ha})$. Lowest yield was obtained in inoculated control (53.62 t/ha). Cost-benefit ratio was high in tebuconazole treated plots compared to all other treatments. The results are in accordance with a recent field study in which azoxystrobin+difenaconazole sprays were effective in management of whip smut of sugarcane (Udhayakumar et al., 2019) ${ }^{[19]}$. Similarly, Bhuiyan et al. (2012) ${ }^{[4]}$ reported the suppression of smut disease on sett 
treatment with azoxystrobin, cyproconazole, triadimefon and Propiconazole.

Newer antifungal agents like triazoles or strobilurins are the fungicides with novel modes of action with broad spectrum activity. Triazoles are largest group of antifungal agents that inhibits P450 14 $\alpha$-demethylase involved in conversion of lanosterol to ergosterol. Inhibition of this enzyme results in sterol accumulation which leads to malfunction of membrane proteins thus causing permeability change (Shalini et al., 2011) ${ }^{[17]}$. On the other hand, Strobilurins or $Q_{0} I$ group of fungicides are the most important chemicals used for plant protection against broad spectrum of diseases and are regarded as reduced-risk fungicides by Environmental Protection Agency of United States. Strobilurins inhibit mitochondrial respiration in fungi by binding to the $\mathrm{Q}_{0}$ site of cytochrome b (Bartlett et al., 2002) ${ }^{[2]}$. These fungicides are excellent preventive fungicides as they kill germinating spores effectively; however, the translaminar movement concerns curative disease control. In the present study, among the fungicides tested, azoxystrobin + tebuconazole was found highly effective as sett treatment of seed cane in plant crop and spray of tebuconazole or azoxystrobin+tebuconazole twice in ratoon crop. This may be attributed to the strong affinity of azoxystrobin to the cuticle which may reduce its efficacy in inhibiting $S$. scitamineum mycelium systemically infecting sugarcane.

It can be concluded from the two years study that dipping of seed cane in azoxystrobin+tebuconazole@0.1\% for $15 \mathrm{~min}$ has reduced the smut incidence in plant crop and spraying twice with tebuconazole@0.1\% immediately on ratoon initiation and second spray at 30 days after ratooning had effectively managed whip smut of sugarcane under field conditions and resulted in enhanced cane yield compared to untreated control.

Table 2: Effect of sett treatment with fungicides on whip smut incidence in sugarcane (Plant crop)

\begin{tabular}{|c|c|c|c|c|c|}
\hline \multirow{2}{*}{ Treatment } & Particulars & $\begin{array}{c}\text { Per cent Disease } \\
\text { incidence 2017-18 }\end{array}$ & $\begin{array}{c}\text { Per cent Disease } \\
\text { incidence 2018-19 }\end{array}$ & $\begin{array}{c}\text { Per cent Disease } \\
\text { incidence (Pooled data) }\end{array}$ & $\begin{array}{c}\text { Per cent disease } \\
\text { reduction over } \\
\text { control (\%) }\end{array}$ \\
\hline T1 & Azoxystrobin + Tebuconazole @ 0.1\% & $4.62(12.25)$ & $2.44(8.73)$ & $3.53(10.67)$ & $8{ }^{*}$ \\
\hline T2 & Trifloxystrobin + Tebuconazole @ 0.1\% & $6.18(14.27)$ & $3.68(10.99)$ & $4.93(12.80)$ & 88.11 \\
\hline T3 & Propiconazole @0.1\% & $6.28(14.43)$ & $3.11(9.59)$ & $4.69(12.33)$ & 83.39 \\
\hline T4 & Difenaconazole @0.1\% & $10.81(19.08)$ & $5.62(13.61)$ & $8.22(16.56)$ & 7.20 \\
\hline T5 & Tebuconazole @ 0.1\% & $7.54(15.87)$ & $5.41(12.83)$ & $6.48(14.57)$ & 78.17 \\
\hline T6 & Carbendazim @ 0.1\% & $24.78(29.79)$ & $15.79(23.45)$ & $20.29(26.68)$ & 31.66 \\
\hline T7 & Hexaconazole @ 0.2\% & $14.91(22.56)$ & $5.43(13.09)$ & $10.17(18.56)$ & 65.74 \\
\hline T8 & Inoculated control & $36.46(37.04)$ & $22.93(28.49)$ & $29.69(32.98)$ & \\
\hline T9 & Healthy control & $15.51(22.96)$ & $6.34(14.41)$ & $10.93(19.23)$ & - \\
\hline & CD (0.05) & 5.72 & 5.14 & 3.84 & \\
\hline
\end{tabular}

*Figures in parenthesis are angular transformed values

Table 3: Effect of fungicide sprays on whip smut incidence in sugarcane (Ratoon crop)

\begin{tabular}{|c|c|c|c|c|c|}
\hline Treatment & Particulars & PDI 2018-19 & PDI 2019-20 & PDI Pooled & $\begin{array}{c}\text { Per cent disease reduction } \\
\text { over control (\%) }\end{array}$ \\
\hline T1 & Azoxystrobin + Tebuconazole @0.1\% & $9.14(17.42)$ & $9.62(17.92)$ & $9.38(17.81)^{*}$ & 69.84 \\
\hline T2 & Trifloxystrobin + Tebuconazole @ 0.1\% & $8.79(16.90)$ & $4.17(11.59)$ & $6.48(14.53)$ & 79.17 \\
\hline T3 & Propiconazole @ 0.1\% & $12.62(20.71)$ & $12.35(20.43)$ & $12.48(20.64)$ & 59.88 \\
\hline T4 & Difenaconazole @0.1\% & $18.34(25.28)$ & $19.87(26.40)$ & $19.11(25.91)$ & 38.57 \\
\hline T5 & Tebuconazole @ 0.1\% & $4.06(10.79)$ & $5.79(13.83)$ & $4.93(12.53)$ & 84.15 \\
\hline T6 & Carbendazim @ 0.1\% & $24.22(29.43)$ & $23.64(29.06)$ & $23.93(29.25)$ & 23.07 \\
\hline T7 & Hexaconazole @ 0.2\% & $13.75(21.37)$ & $14.82(22.56)$ & $14.29(22.18)$ & 54.06 \\
\hline T8 & Inoculated control & $29.83(32.83)$ & $32.39(34.65)$ & $31.11(33.81)$ & - \\
\hline T9 & Healthy control & $16.80(24.10)$ & $17.22(24.34)$ & $17.01(24.27)$ & \\
\hline & CD (0.05) & 7.94 & 4.93 & 4.58 & \\
\hline & CV \% & 20.58 & 12.66 & 11.75 & \\
\hline
\end{tabular}

*Figures in parenthesis are angular transformed values

Table 4: Effect of fungicide sprays on cane yield in sugarcane (Ratoon crop)

\begin{tabular}{|c|c|c|c|c|c|}
\hline Treatment & Particulars & Yield (t/ha) 2018-19 & Yield (t/ha) 2019-20 & Yield (t/ha) Pooled & BC ratio \\
\hline $\mathrm{T} 1$ & Azoxystrobin + Tebuconazole @0.1\% & 71.00 & 70.19 & 70.59 & 1.75 \\
\hline $\mathrm{T} 2$ & Trifloxystrobin + Tebuconazole @ $0.1 \%$ & 75.33 & 74.61 & 74.97 & 1.83 \\
\hline T3 & Propiconazole @ $0.1 \%$ & 70.00 & 68.46 & 69.40 & 1.74 \\
\hline $\mathrm{T} 4$ & Difenaconazole@0.1\% & 62.33 & 63.04 & 62.69 & 1.54 \\
\hline T5 & Tebuconazole@0.1\% & 77.00 & 73.23 & 75.11 & 1.88 \\
\hline T6 & Carbendazim @0.1\% & 61.67 & 59.88 & 60.77 & 1.52 \\
\hline $\mathrm{T} 7$ & Hexaconazole @ $0.2 \%$ & 69.33 & 65.67 & 67.50 & 1.69 \\
\hline $\mathrm{T} 8$ & Inoculated control & 53.00 & 54.25 & 53.62 & - \\
\hline \multirow[t]{3}{*}{ T9 } & Healthy control & 65.00 & 63.91 & 64.46 & - \\
\hline & $\mathrm{CD}(0.05)$ & 12.43 & 11.71 & 11.25 & \\
\hline & $\mathrm{CV} \%$ & 10.59 & 10.17 & 9.68 & \\
\hline
\end{tabular}




\section{References}

1. Abera T, Firehun Y, Solomon B. Review of sugarcane protection research in Ethiopia. In: Abraham $\mathrm{T}$ (ed.) Increasing crop production through improved plant protection: Plant Protection Society of Ethiopia, Addis Ababa, Ethiopia. 2009; 2:409-447.

2. Bartlett DW, Clough JM, Godwin JR, Hall AA, Hamer M, Parr-Dobrzanski B. The strobilurin fungicides. Pest Management Science. 2002; 58:649-662.

3. Bharathi V. Chemical control of sugarcane smut through sett treatment with fungicides. International Journal of Plant Protection. 2009; 2(2):151-153.

4. Bhuiyan SA, Croft BJ, James RS, Cox MC. Laboratory and field evaluation of fungicides for the management of sugarcane smut caused by Sporisorium scitamineum in seed cane. Australasian Plant Pathology. 2012; 41(6):591-599.

5. Bhuiyan SA, Croft BJ, Tucker GR. New method of controlling sugarcane smut using flutriafol fungicide. Plant Disease. 2015; 99:1367-1373.

6. Chona BL. Sugarcane smut and its control. Indian Farming. 1943; 4:401-404.

7. FAOSTAT, 2018. http://www.fao.org/faostat/en/\#data/QC accessed on 23.06.2020.

8. Ferreira SA, Comstock JC. Smut. In 'Diseases of sugarcane'. (Eds C Ricaud, BT Egan, AG Gillaspie Jr, CG Hughes), 1989, 211-229. (Elsevier: Amsterdam)

9. James G. Effects of rouging on yield and smut of sugarcane. Experimental Agriculture. 1973; 9(1):73-82.

10. Liu S, Lin $\mathrm{N}$, Chen $\mathrm{Y}$, Liang, et al. Biocontrol of sugarcane smut disease by interference of fungal sexual mating and hyphal growth using a bacterial isolate. Frontiers in Microbiology. 2017, 8. doi: 10.3389/fmicb.2017.00778.

11. Mohan Rao NV, Prakasam P. Studies on sugarcane smut. Proceedings of International Society of Sugarcane Technology. 1956; 1:1048-057.

12. Panse VG, Sukatme PV. Statistical methods for agricultural workers. Indian Council of Agricultural Research Publication, New Delhi. 1985, 87-89.

13. Paramdeep S, Bipen K, Meeta JM, Ritu R. Management of sugarcane smut (Ustilago scitaminea) with fungicides and bio-agents. African Journal of Microbiology Research. 2014; 8(51):3954-3959.

14. Ramesh Sundar A, Barnabas EL, Malathi P, Viswanathan R. A Mini-review on smut disease of sugarcane caused by Sporisorium scitamineum, Botany, Dr. John Mworia (Ed.), ISBN: 978-953-51-0355-4, In Tech, 2012. Available from: http://www.intechopen.com/books/botany/-a-minireview-on-the-status-of-smut-disease-of-sugarcanecaused-by-sporisorium-scitamineum

15. Robinson RA. Sugarcane smut. Est African Agricultural and Forestry Journal. 1959; 24:240-343.

16. Sandhu SA, Bhatti DS, Rattan BK. Extent of losses caused by smut (Ustilago scitaminea Syd.) Journal of Research (PAU). 1969; 6:341-344.

17. Shalini K, Kumar N, Drabu S, Sharma PK. Advances in synthetic approach to and antifungal activity of triazoles. Beilstein Journal of Organic Chemistry. 2011; 7:668-677.

18. Sundravadana S, Ragava T, Thirumurugan A, Sathiya K, Shah E. Impact of weather factors and mitigation approaches on sugarcane smut disease. SISSTA Sugar Journal. 2011; 39:59-64.
19. Udhayakumar R, Muthukumar A, Kanagarajan R. Field evaluation of new fungicide molecule (Amistar Top 325 Sc) against sugarcane smut incited by Sporisorium scitamineum. International Archive of Applied Sciences and Technology. 2019; 10(2):13-17.

20. Viswanathan R, Rao GP. Disease scenario and management of major sugarcane diseases in India. Sugar Tech. 2011; 13:336-353.

21. Wada AC, Anaso AB, Bassey MS. Sugarcane whip smut (Sporisorium scitamineum Syd) caused field sucrose and juice quality losses of two sugarcane varieties in Nigeria. International Journal of Plant and Soil Science. 2016; 10(4):1-11.

22. Wada AC, Dangana S. Management of whip smut of sugarcane (Sporisorium scitamineum Sydow \& h. sydow.) with some plant extracts with fungicidal actions. Natural Products. 2016; 12(1):031-037.

23. Xiupeng S, Fenglian M, Krishan KV, Jinju W, Xiaoqiu $\mathrm{Z}$, Litao $\mathrm{Y}$ et al. Effect of sugarcane smut (Ustilago scitaminea Syd.) on ultrastructure and biochemical indices of sugarcane. Biomedical Journal of Scientific and Technical Research. 2019; 17(1):12546-12550. 